\title{
In the Shadow of Islam (review)
}

\author{
Barbara Oudová Holcátová
}

In the Shadow of Islam: Minority Religions in the Middle East is a monograph on the topic of non-Islamic religions that can be found in the Middle East, with particular focus on the recent history of these religious groups and their current situation. The book is intended as an overview for an educated non-expert audience, however, it does not disguise that it is not exhaustive or even entirely representative of the situation of religious minorities in the Middle East.

There is generally very little idea among Czech laymen about non-Islamic religions in the Middle-East. Presently there exists a great mistrust of Islam, which sometimes generates sympathies for these groups, which they would otherwise not garner given a degree of negativity with which anything Middle-Eastern tends to be viewed in Czech society. At the same time, there is often little other information about these groups among the Czech public, other than the mere fact that they are being persecuted by either Muslim governments or radical and terrorist organizations in the area. In this light, a book like this is an invaluable contribution to the available Czech writing on the topic of both religious studies and the Middle East. Simultaneously, by its mosaic nature and detailed explanation of historical backgrounds, it also contributes to the frequently over-simplified image of the Middle East that tends to prevail in the general Czech idea of the region. In some ways, there is no better way to break the image than exploring how the situation of different religious groups is interconnected and tied to every aspect of the region's political and religious landscape. In this sense, its importance cannot be overstated.

Nevertheless, a reader looking for more than widening their knowledge of the Middle East can on occasion be disappointed. The book would benefit from a clearer conception, or a more unified execution. The foreword declares that given the different realities of the different communities, there was no point in creating one universal framework the individual chapters would follow. That is certainly true, and the very different religions that can be found in the Middle East require very different approaches. Still, this does not fully explain the vast differences where some chapters are focused purely on history, and chiefly recent history, while other speak much more of religious teachings and sometimes religious practice of the said groups. This does not detract from the erudition displayed in these chapters, but it makes the book less coherent as a whole, and the image of the Middle East it presents is a little less complete for this. 
The choice of which religious groups to include is sometimes a little questionable as well - the claim that Judaism was excluded because of the very complicated relationship of politics and religions related to that in the Midde East is perhaps acceptable, but the exclusion of Baha'i or Zoroastrism is difficult to explain away, particularly in light of the inclusion of much more marginal communities. Any publication that includes the Shabak and the Yaresan but excludes Baha'i skews the picture of the Middle East it presents, however much it is declared in the beginning that the reason for the choice of the included religions lay chiefly in the availability of Czech experts on the topic. Perhaps the fact that the book is aimed at least partly at the public makes it the most problematic - after all, experts do not need to be informed of the existence of the Baha'i faith. Still, this books remains the only one to let the public know about many of the other religious groups included, and no omissions, however marked, take away from that.

The book is divided into sections of general introduction, Christian groups in the Middle East, religions related to Islam, and other relevant religions in the region. In the general introduction, Bronislav Ostřanskýs chapter concerns the relationship of Islam to minority religions, both in the theory of theology and Sharia and in practice. This provides crucial context for what we find later in the book, and in fact the publication could have benefited from a little longer exposé on this topic, but all the key points were covered in the short space.

Stefano Taglia's piece about religion in Ottoman Empire is much longer. It covers the Empire's approach towards its religious minorities, as well as a rather detailed history of the realm in relation to them. As a sort of long addendum, there is a recapitulation of post-Second World War Middle-Eastern history. This is the chapter that perhaps shows the unclear goal of the book best. While fascinating in itself, it goes into great detail and has the character of an original journal article more than a summarizing piece in a monograph. The addendum about the early $20^{\text {th }}$ century is much needed, though it is so different in style from the first part that it can effectively be considered a separate chapter.

Michal Routil is the author of the introductory chapter on Christianity in the Middle East, which provides a historical summary as well as an overview of the relevant denominations. It is succinct and exhaustive, though his own personal sympathies towards Christianity show through rather markedly in some places. Ǩoutil is also the author of a very detailed article about the Assyrian Church of the East and its branches, which focuses mainly on its history, though it does provide a more detailed overview of the theology towards the end. It is perhaps a little confusing for non-expert readers, especially given that it uses different names for the same religious organization.

Petra Koštálová introduces the readers to the Armenian Church, which focuses almost exclusively on its history, but does it in a beneficent and clear manner that makes it easy for non-experts to follow, without the information contained suffering in any way. 
Viola Pargačová writes about Coptic Christianity, uniquely covering very many aspects - from history through teachings and practice to the current situation both in Egypt and in the diaspora. Some parts are a little unclear and confusing, but the current situation is examined with a great deal of detail and written in an accessible manner. The value of the examination of ritual practice in this chapter, too, cannot be overstated, since it is so rarely found in any resource on Christianity.

Monika Langrock's chapter on Maronite Christianity gives an overview of the demographic situation and then focuses on modern history, which is deeply interlinked with the history of Lebanon as a whole. The text is a little inaccessible to non-theologians, since she uses theological terms without clear explanations at times, but offers detailed information and context especially for the modern situation.

The next section of the book deals with minority religions that relate to Islam. The first chapter is Luboš Kropáček's contribution on the Alawis. It offers a balanced and accessible overview of theology and history, though there is little mention of religious practice. There is a focus on modern history, and at times the lack of explanation of specific terminology can be a little confusing for non-experts too. Kropáček’s chapter about the Druze shares the positive qualities of his first one, and additionally includes some essential information on religious practice.

Kateřina Vytejčková's chapter about the Alevis is among the best contributions of this book. It offers a very balanced and accessible account of the religious group in question, and in this case the section about religious practice deserves special attention, for the author's fieldwork in the area shows, without a doubt, the invaluable nature of such expertise. The more theory-focused parts of the article are not lacking in any way, however, and the section on identity stands out as worthy of any reader's attention.

Petr Kubálek's contribution about the Shabak and the Yaresan is perhaps a little unstructured and confusing in places, but it is also unique in being one of the very few pieces written about these religious groups in Czech, and deserves a high degree of attention for this alone. Additionally, it is a well-balanced account of the teaching and history of said religious groups.

The last section concerns religions unaffiliated with any major tradition, and contains two articles. The first is Petr Kubálek's piece about the Yazid, which, just like his previous piece, deserves attention for being a well-balanced overview and provides good information about the Yezidi religious practice.

The last article is by Jiří Gebelt, and focuses on the Mandean community. It provides a good (though a little compressed) introduction into teachings and religious practice, and a detailed account of modern history and contemporary situation. Attention should be called to the analysis of recent changes in ritual practice as the community reacts to its changed living conditions.

There is also a photography section to be found in the book, containing pictures which perfectly complete the image presented by providing the readers with a visual guide to different religious groups, something that is without a doubt an extremely 
important aspect in understanding the richness of these traditions. All in all, while perhaps not wholly balanced or entirely comprehensive, this book is an absolutely crucial contribution to the available Czech literature on the Middle East and on smaller religious communities in general.

JiŘí Gebelt et al., Ve stínu islámu: Menšinová náboženství na Blizkém východě, Praha: Vyšehrad 2017, 445 p. 